\title{
POSTULAÇÃO DE GENES (Lr) DE RESISTÊNCIA À FERRUGEM DA FOLHA EM CULTIVARES BRASILEIRAS DE TRIGO*
}

\author{
SANDRA M. ZOLDAN ${ }^{1} \&$ AMARILIS L. BARCELLOS ${ }^{2}$
}

${ }^{1}$ Universidade de Passo Fundo, Faculdade de Agronomia e Medicina Veterinária, Cx. Postal 611, 99001-970, Passo Fundo; ${ }^{2}$ Embrapa Trigo, Cx. Postal 451, 99001-970, Passo Fundo, RS, e-mail: amarilis@cnpt.embrapa.br

(Aceito para publicação em 02/07/2002)

Autor para correspondência: Amarilis L. Barcellos

ZOLDAN, S.M. \& BARCELLOS, A.L. Postulação de genes $(L r)$ de resistência à ferrugem da folha em cultivares brasileiras de trigo. Fitopatologia Brasileira 27:508-516. 2002.

\section{RESUMO}

Vinte e dois isolados que diferem quanto aos genes de avirulência/virulência de Puccinia triticina foram inoculados em 55 genótipos de trigo (Triticum aestivum) selecionados entre os recomendados e em experimentação na região sul e centro sul do Brasil nos anos de 1996 e/ou 1997 e em linhas monogênicas para genes $(L r)$ de resistência à ferrugem da folha, no estádio de plântula. Os tipos de infecção dos genótipos portadores, cada um de distinto gene $L r$ conhecido foram comparados com os dos genótipos brasileiros, para determinar a existência de possíveis genes de resistência nestes. Os genes de plântula identificados com mais freqüência nas cultivares e linhagens brasileiras foram: $L r 26, L r 23$, $L r 10$ e $L r 24$. O gene $L r 16$, que confere resistência moderada à maioria das raças, foi encontrado em apenas dois genótipos. Muitos dos trigos analisados possuem um ou mais genes $L r$ provavelmente ainda não descritos.

Palavras-chave adicionais: Triticum aestivum, Puccinia recondita f. sp. tritici, $P$. triticina, genes de resistência de plântula.

\section{ABSTRACT \\ Postulation of genes $(\mathrm{Lr})$ for resistance to leaf rust in Brazilian wheat cultivars}

In 1996 and 1997 in the southern and central-southern regions of Brazil, a field trial evaluation was peformed on 55 wheat (Triticum aestivum) genotypes representing the recommended cultivars or the advanced inbred lines, as well as differentials for $L r$ known genes which confer resistance to leaf rust. The wheat genotypes were inoculated at seedling stage with 22 isolates having different avirulent/ virulent genes of Puccinia triticina. The types of infection resulting from these inoculations were examined and by comparison, the occurrence of resistance genes in the tested Brazilian genotypes was determined. The seedling resistance gene more frequently identified in the Brazilian genotypes were $L r 26, L r 23, L r 10$ and $L r 24$. The $L r 16$ gene, that confers moderate resistance to most of the fungus races, was only found in two genotypes. Many of the analyzed wheat genotypes have one or more $\mathrm{Lr}$ genes probably not yet described.

\section{INTRODUÇÃO}

A ferrugem da folha do trigo (Triticum aestivum L.) causada pelo fungo Puccinia triticina Eriks, anteriormente referida como Puccinia recondita Roberge ex Desmaz. f. sp. tritici está disseminada em todo o mundo e, ao contrário das outras ferrugens desse cereal, ocorre todos os anos no Brasil, causando graves prejuízos, pois, normalmente, as condições climáticas das regiões produtoras favorecem o aparecimento e o rápido desenvolvimento da doença.

O principal método de controle recomendado para essa doença é o cultivo de cultivares resistentes. $\mathrm{O}$ conhecimento da presença ou ausência de genes de resistência em cultivares e linhagens é importante para a identificação e caracterização de germoplasma resistente.

Flor (1959) demonstrou, usando o patossistema linho [Melampsora lini (Pers.) Lév.] a existência de uma relação um-a-um, entre genes de ataque e de defesa, respectivamente,

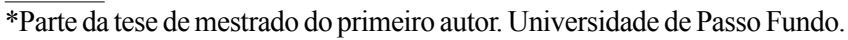

no patógeno e no hospedeiro, dando origem à hipótese de Flor: para cada gene que condiciona uma reação de resistência no hospedeiro existe um gene complementar, no patógeno, que condiciona avirulência. Esta hipótese foi expandida por Person (1959), que sugeriu a aplicação em outros sistemas parasita:hospedeiro. Baseado no conceito gene-a-gene e na genética das associações patógeno-hospedeiro, a presença de gene(s) de resistência no hospedeiro pode ser demonstrada, considerando-se tipos de infecção alto (suscetibilidade) e baixo (resistência), produzidos na cultivar como os conferidos por conhecidos genes de resistência $(L r)$ à ferrugem da folha, quando as plantas são infetadas, utilizando-se adequadas combinações de genes para avirulência e virulência no patógeno (raças). O fenótipo das interações hospedeiroparasita é o tipo de infecção. Uma interação compatível ou incompatível entre patógeno-hospedeiro é chamada tipo de infecção alto ou baixo, respectivamente (Loegering, 1984). Este conceito tem sido usado com sucesso na postulação de genes para resistência em plântula a $P$. triticina em vários centros de pesquisa do mundo (Modawi et al., 1985; Dubin 
et al., 1989; McVey \& Long, 1993; Kolmer \& Dyck, 1994; Rizvi \& Buchenau, 1994).

No trigo, mais de 50 genes $L r$, para resistência à ferrugem da folha foram descritos (McIntosh et al., 1995a; McIntosh et al., 1995b; Singh et al., 1998).

No Brasil, há pouca informação disponível sobre a genética da resistência ao organismo causal da ferrugem da folha do trigo, embora seja satisfatório o nível de conhecimento sobre a virulência da população patogênica.

O objetivo deste estudo foi identificar genes de resistência de plântula (resistência que se expressa desde a primeira folha até a folha bandeira) à ferrugem da folha, presentes em cultivares de trigo, selecionadas entre as recomendadas para cultivo e em experimentação oficial nas regiões sul e centro sul do Brasil. O conhecimento da presença ou ausência de genes de resistência visa informar os melhoristas na escolha dos genitores para cruzamentos.

\section{MATERIAL E MÉTODOS}

As sementes dos genótipos de trigo brasileiros nos quais os genes $L r$ foram postulados (Tabela 1) e as dos genótipos com $L r$ conhecidos (Tabela 2), bem como o inóculo das raças de $P$. triticina foram fornecidos pela Embrapa Trigo. Os genótipos introduzidos são originários do Canadá, Austrália e Estados Unidos da América do Norte (McIntosh et al., 1995b).

As raças de $P$. triticina (Tabela 2 ) foram caracterizadas anteriormente, conforme o sistema de nomenclatura norteamericano (Long \& Kolmer, 1989) e o nacional correspondente, pela avirulência/virulência a 19 genes $L r: L r 1, L r 2 a$, Lr2c, Lr3, Lr3ka, Lr9, Lr10, Lr11, Lr14a, Lr14b, Lr16, Lr17, Lr18, Lr20, Lr21, Lr23, Lr24, Lr26 e Lr30. O tipo de infecção (Tabela 2) da interação dos isolados das 22 raças e dos genes $L r$ referidos, além de $L r 2^{4} d, 3 b g, 13,19,25$, $27+31,33,34,34+T 3$ e $T 2$ foi obtido visando auxiliar na postulação dos genes das cultivares e linhagens brasileiras. Dados não apresentados da interação dos mesmos isolados aos genes $\operatorname{Lr} 28$ (Chinese Spring (CS) 2A/2M e CS 2D/2M), Lr29 (CS 7D/7AG), Lr32 (Marquis*6/RL5713), Lr12 (RL6011), Lr15 (Thatcher*6/W1483) e T3 (Thatcher-LrT3 originado de Terenzio) foram obtidos. Os genes $\operatorname{Lr} 27$ e 31 são complementares e atuam para a resistência somente se estiverem juntos (Singh \& McIntosh, 1984).

Dez sementes de cada cultivar de trigo, tratadas com Iprodione + Thiran, foram semeadas em copos plásticos com $150 \mathrm{~g}$ de solo de mata. A acidez foi corrigida com calcário e adicionou-se adubação recomendada pela análise de solo. Urediniosporos de cada raça, em suspensão de óleo mineral Soltrol, foram inoculados na $1^{\text {a }}$ folha expandida após estas terem sido pulverizadas com água e, aproximadamente, duas gotas por litro de Tween 20. Após 16 h em câmara úmida, na ausência de luz, com saturação de umidade sem escorrimento, à temperatura de $20^{\circ} \mathrm{C}$, as plântulas foram transferidas para casa de vegetação, sob condições naturais de luminosidade, umidade relativa na faixa de $60-80 \%$ e temperatura de cerca de $20^{\circ} \mathrm{C}-3$, tendo, por curtos períodos de tempo, esta atingido $36{ }^{\circ} \mathrm{C}$. O tipo de infecção foi avaliado dez a 12 dias após a inoculação.

O procedimento para estimar o tipo de infecção foi o internacionalmente utilizado, através dos símbolos $0, ;, 1,2$, 3, 4 e X (reação heterogênea: uredia de tamanho variável, distribuídas ao acaso na folha). Os sinais + ou - expressam graus de variação na reação (Roelfs et al., 1992). Tipos de infecção 3 e 4 são considerados altos, correspondendo à suscetibilidade no hospedeiro, e os demais, à resistência.

A presença ou ausência dos genes de resistência à ferrugem da folha foi postulada pela comparação, quanto ao tipo de infecção a cada raça de $P$. triticina, das plântulas da cultivar cujos genes de resistência se desconhecia, com as plântulas das linhagens que possuem os genes de resistência em questão (monogênicas). As reações, individuais a cada raça, foram obtidas sob as mesmas condições, evitando-se interferência desuniforme de temperatura, umidade e luz nos sintomas.

Os principais passos considerados para postular a presença dos genes de resistência, conforme Dubin et al. (1989), foram os seguintes:

1) Se a monogênica para um determinado gene $L r$ conhecido e a cultivar/linhagem apresentam o mesmo padrão, quanto ao tipo de infecção, alto (suscetibilidade) e baixo (resistência), com uma série de isolados (raças), postula-se a presença do mesmo gene.

2) Se a monogênica para um gene $L r$ é resistente a um determinado isolado e a cultivar/linhagem brasileira reage como suscetível, então esta não é portadora do referido gene.

3) Se o isolado produz tipo de infecção de resistência diferente, quando comparado à do $L r$ conhecido com o da cultivar/ linhagem avaliada, há indicação da presença de diferentes genes. Contudo, é conhecido que a expressão de genes de resistência pode ser influenciada pela constituição genética (background) e deve haver precaução na interpretação de tais resultados.

4) Se o genótipo para a obtenção da presença ou ausência do gene apresenta reação mais resistente que a monogênica para o $L r$ conhecido, poderá tratar-se do mesmo gene mas, em adição poderá haver outro, epistático.

5) Se um gene conhecido produz tipo de infecção característico em determinados ambientes, isto poderá ser usado para sustentar a postulação da presença do gene.

6) A indicação de um gene conhecido em uma cultivar/ linhagem pode também ser baseada na sua genealogia. Os ancestrais deverão ser averiguados, para identificar os possíveis doadores dos genes e sustentar os resultados. Mais detalhes deste método podem ser encontrados em Modawi et al. (1985) e Rizvi \& Buchenau (1994).

A condução de estudos de postulação de genes através da comparação dos dados de reação da cultivar analisada a vários isolados com combinações diferentes de genes de avirulência/virulência, pelo tipo de infecção, com linhagens portadoras de um gene de resistência, continua a ser ferramenta confiável nos centros de melhoramento, em todo o 
TABELA 1 - Cultivares e linhagens de trigo (Triticum aestivum) às quais genes de resistência à ferrugem da folha foram postulados e respectivos cruzamentos

\begin{tabular}{|c|c|}
\hline CULTIVAR/LINHAGEM & CRUZAMENTO \\
\hline ANAHUAC 75 & II 12300//LERMA ROJO 64/8156/3/NORTEÑO 67 \\
\hline CEP 11 & PF $6968 * 2 / H A D D E N$ \\
\hline CEP 14-TAPES & PEL 72380/ARTHUR 71 \\
\hline CEP 24-INDUSTRIAL & BR 3/CEP 7887//CEP 7775/CEP 11 \\
\hline CEP 27-MISSÕES & CEP 8057/BUTUI//CEP 8324 \\
\hline COODETEC 101 (OC 939) & AU//UP 301//MAITACA \\
\hline EMBRAPA 119 (PF 9198, BRS119) & PF 82252/ BR 35//IAPAR 17/PF 8550 \\
\hline EMBRAPA 120 (PF 91205, BRS 120) & PF 83899/PF 813//F27141 \\
\hline EMBRAPA 15 & CNT 10/BR 5//PF 75172/TIFTON 72-59 SEL \\
\hline EMBRAPA 16 & HULHA NEGRA/CNT 7//AMIGO/CNT 7 \\
\hline EMBRAPA 24 & TIF SEL/PF 79763/3/NBOZU/3*LD//B 7902 \\
\hline EMBRAPA 27 (PF 869107) & $\mathrm{PF} 83743 / 5 / \mathrm{PF} 83182 / 4 / \mathrm{CNT} 10 * 4 / / \mathrm{LV} * 5 / \mathrm{AGA} / 3 / \mathrm{LD} * 4 / \mathrm{AGENT} / / \mathrm{LD} * 3 / \mathrm{NBAY}$ \\
\hline EMBRAPA 40 & PF $7650 /$ NS 18-78//CNT 8/PF 7577 \\
\hline EMBRAPA 49 (BRS 49) & BR 35/PF 83619//PF 858/PF 8550 \\
\hline EMBRAPA 52 & HULHA NEGRA/CNT 7//AMIGO/CNT 7 \\
\hline FRONTANA & FRONTEIRA/MENTANA \\
\hline FUNDACEP 29 (CEP 9019) & BR 23/CEP 8423//BUC SIB \\
\hline IAC 5-MARINGÁ & FRONTANA/KENYA 58//PG 1 \\
\hline IAPAR 17-CAETÉ & JUPATECO 73/BLUEJAY SIB \\
\hline IAPAR 28-IGAPÓ & KAVKAZ/BUHO SIB//KALYAN/BLUEBIRD, VEERY 3, GENARO F 81 \\
\hline IAPAR 29-CACATU & BLUEJAY SIB/JUPATECO 73, OPATA 85 \\
\hline IAPAR 46 & MASCARENHAS/ALONDRA SIB//IAC 5 \\
\hline IAPAR 53 & SULINO/IA 7929 \\
\hline IAPAR 6-TAPEJARA & DESCONHECIDO \\
\hline IAPAR 60 & BLUEJAY SIB/JUPATECO 73//TANAGER SIB \\
\hline IAPAR 78 & VEERY SIB/BOW SIB \\
\hline IAPAR 84 (PG 9337, IPR 84) & ANA/PF 7455//PF 72556/3/PAM SIB/ALD SIB//KAVKO SIB \\
\hline MANITOBA 97 (IDS 93421) & VEERY 5/PANDA \\
\hline OC 9511 (CD 103) & PG 864/IOC 856 \\
\hline OC 959 & LD*6/KVZ//LD*6/AGENT/LD*6/KVZ/LD*6/WTP/4/IAS 63/ALDAN SIB \\
\hline OCEPAR 10-GARÇA & IAC 5/ALDAN SIB \\
\hline OCEPAR 14 & IAS 64/ALDAN SIB/6/COC 75/5/PICHON/4/KT 54*2/N 10B//K 54B/3/NAR 59 \\
\hline OCEPAR 15 & CNT 7//KAVKAZ/BUHO SIB/3/PEL 72390 \\
\hline OCEPAR 16 & SISKIN SIB/VEERY SIB \\
\hline OCEPAR 18 & KAVKAZ/BUHO SIB//KALYAN/BLUEBIRD, VEERY SIB \\
\hline OCEPAR 21 & CEP 11/4/KALYAN/BLUEBIRD//CAJEME SIB/3/ALONDRA SIB \\
\hline OCEPAR 22 & KALYAN/BB//CJ SIB/3/ALD SIB/4/RS 3 \\
\hline OCEPAR 23 (CD 102) & IAC 5/ALDAN SIB//CEP 7780 \\
\hline OR 1 & PF 869107 SIB/BAU SIB \\
\hline PANDA & IDS 1528/SA 45//PARAGUAY 281 \\
\hline PELADINHO & DESCONHECIDO \\
\hline PF 9099 & PF 82252/BR 35//IAPAR 17/PF 8550 \\
\hline PF 91450 & BR 12*3/PF 8342/4/BR 12*3/3/IAS 55*4/CI 14123//IAS 55*4/EAGLE \\
\hline PF 9293 (BRS 177) & PF 83899/PF 813//F27141 \\
\hline RS 1-FÊNIX & PF 70100/J 15157-69 \\
\hline RS 8-WESTPHALEN & CNT 10/BURGAS 2//JACUI \\
\hline RUBI (ORL 9285) & PF 869107/KLH 3450 C 3131 \\
\hline SA 9458 (FEPAGRO - RS 15) & PF $82250 /$ RS 1 \\
\hline TOROPI & PETIBLANCO 8//FRONTANA 1971-37/QUADERNA A \\
\hline TRIGO BR 15 & IAS $54 * 2 /$ TOKAI 80//PF 69193 \\
\hline TRIGO BR 18-TERENA & DESCONHECIDO \\
\hline TRIGO BR 23 & CORRE CAMINOS/ALONDRA SIB/3/IAS 5420/ COTIPORÃ//CNT8 \\
\hline TRIGO BR 32 & IAS 60/INDUS//IAS 62/3/ALONDRA SIB/4/IAS 59 \\
\hline TRIGO BR 35 & IAC $5 * 2 / 3 /$ CNT $7 * 3 /$ LONDRINA//IAC 5/ HADDEN \\
\hline TRIGO BR 38 & IAS 55*4/AGENT//IAS 55*4/CI 14123 \\
\hline
\end{tabular}

mundo. Constitui também, identificação rápida dos genes de resistência às ferrugens (quatro a oito semanas, em comparação a dois anos pela análise genética) e permite prévia eliminação de genes não efetivos, proporcionando assim, fontes mais eficientes de resistência para o controle de doenças (Rizvi \& Buchenau, 1994).

Como por esta metodologia se indica, mas não se pode demostrar a presença de um gene, uma vez feita uma 
TABELA 2 - Tipos de infecção* em plântulas exibidos pelas linhagens de trigo (Triticum aestivum) portadoras de distintos genes $L r$, quando testadas a 22 raças de Puccinia triticina

\begin{tabular}{|c|c|c|c|c|c|c|c|c|c|c|c|c|c|c|c|c|c|c|c|c|}
\hline \multirow{3}{*}{ Linhagem } & \multirow{3}{*}{$\begin{array}{c}\text { Gene } \\
L r\end{array}$} & \multirow{3}{*}{$\begin{array}{l}\text { NBG/ } / \\
G^{1} \\
B_{10}\end{array}$} & \multirow{3}{*}{$\begin{array}{l}\text { SBJ/ } \\
\text { LQ } \\
\text { B } 14\end{array}$} & \multirow{3}{*}{$\begin{array}{l}\text { NBK/ } \\
\text { MR } \\
\text { B 22 }\end{array}$} & \multicolumn{16}{|c|}{ Raças de Puccinia triticina } \\
\hline & & & & & $\begin{array}{l}\text { LCJ/ } \\
\text { RS }\end{array}$ & $\begin{array}{l}\text { NCH/ } \\
\text { TR }\end{array}$ & $\begin{array}{l}\text { MBR/ } / \\
\text { MR }\end{array}$ & $\begin{array}{l}\text { MBK/ } \\
\text { ML }\end{array}$ & $\begin{array}{l}\text { TDT/ } \\
\text { BL }\end{array}$ & $\begin{array}{l}\text { SDJ/ } \\
\text { QR }\end{array}$ & $\begin{array}{l}\text { CBT/ } \\
\text { HQ }\end{array}$ & $\begin{array}{l}\text { LLK/ } \\
\text { HQ }\end{array}$ & $\begin{array}{l}\text { HCJ/ } \\
\text { JR }\end{array}$ & $\begin{array}{l}\text { MCG/ } \\
\text { RS }\end{array}$ & $\begin{array}{l}\text { MCR/ } \\
\text { CS }\end{array}$ & $\begin{array}{l}\text { MBR/ } \\
\text { RL }\end{array}$ & $\begin{array}{l}\text { SLK/ } \\
\text { HQ }\end{array}$ & $\begin{array}{l}\text { TBJ// } \\
\text { RR }\end{array}$ & $\begin{array}{l}\text { CGT/ } \\
\text { CQ }\end{array}$ & $\begin{array}{l}\text { MFT/ } \\
\text { KS }\end{array}$ \\
\hline & & & & & & & & & & & & & & & & & B 37 & & & B 40 \\
\hline RL6003a & 1 & 3 & 3 & 3 & 3 & 3 & 3 & 3 & 3 & 3 & ; & 3 & 3 & 3 & 3 & 3 & $3^{+}$ & 3 & ; & 4 \\
\hline PF85450 & $2^{a}$ & ; & 3 & ; & 0 & . & 0 & ; & $3^{++}$ & 3 & ; & ; & 3 & 0 ; & 0 & ; & 3 & 3 & 0 & ; \\
\hline RL6019 & $2 b$ & ;2 & 3 & $2-;$ & 0 & $;-1$ & 0 & ; & 3 & 3 & ; & 0 & 3 & 0 & ; & ; & 3 & $3-$ & 0 & ; \\
\hline RL6047 & $2 c$ & 3 & 3 & 3 & 0 & 32 & $; 1$ & ; & 3 & 3 & $; 1$ & $; 1$ & 3 & ; & $; 1$ & ; & 3 & 3 & ; & ; \\
\hline RL6001 & $2^{4} d$ & 3 & 3 & 3 & ; & 2 & ; & ; & 4 & 3 & ;C & ; & 3 & ; & ; & ; & 3 & $3-$ & ; & \\
\hline RL6002 & 3 & $; 1$ & ; & $; 1$ & $; 1$ & $; 1$ & 3 & 3 & $3^{++}$ & $; 1$ & 3 & $23-$ & 3 & 3 & 3 & 3 & 1 & 3 & 3 & $3+$ \\
\hline RL6042 & $3 b g$ & ;1 & ; & $; 1$ & ; & ;C & $3-1$ & $3^{=}$ & 3 & $; 1$ & 3 & $; 1$ & 3 & 3 & $3-$ & 3 & $; 1 \mathrm{C}$ & $3-32$ & $33^{=}$ & $33-$ \\
\hline RL6007 & $3 k a$ & $; 2^{+}$ & $; 1$ & $22^{+} 3$ & $; 1$ & 23 & 3 & $; 1$ & $3+$ & ; & 3 & $23-$ & ; & $; 123^{-}$ & 3 & 3 & $2-3^{=}$ & 1 & 3 & 3 \\
\hline PF85740 & 9 & ; & ; 1 & ;1 & 0 & ; & 0 & ; & ; & ; & ; & 3 & ; & 0 & ; & ; & 3 & 0 & 0 & ; \\
\hline RL6004 ${ }^{\mathrm{a}}$ & 10 & 12 & 3 & 3 & 32 & 3 & 3 & 3 & $; 13=$ & 3 & $; 1$ & $; 1$ & $; 1$ & 3 & ; & 3 & 1 & 3 & ; & $; 1$ \\
\hline RL6048 & 11 & $33^{=}$ & 3 & 3 & 3 & 3 & 3 & 3 & 3 & 3 & 3 & 3 & 3 & 3 & 3 & 3 & 3 & 3 & 3 & 3 \\
\hline Thatcher $\operatorname{Lr} 13$ & 13 & 3 & $33^{-}$ & 3 & 3 & 3 & 2 & 3 & 3 & $33=$ & 32 & $3-$ & 3 & $3-$ & 2 & 3 & 3 & $3-$ & 3 & 32 \\
\hline RL6013 & $14^{a}$ & 3 & 3 & 3 & 3 & 3 & 3 & 3 & 3 & 3 & 3 & 3 & 3 & 3 & 3 & 3 & 3 & 3 & 3 & $3^{-}$ \\
\hline RL6006 & $14 b$ & 3 & 3 & 3 & 3 & 3 & 3 & 1 & $; 1$ & 3 & $3-$ & 3 & 32 & 3 & $3-$ & $;-3^{=}$ & 3 & $3-$ & 3 & 3 \\
\hline RL6005 ${ }^{\mathrm{a}}$ & 16 & 2 & 2 & $22^{+}$ & 2 & 2 & & 2 & 2 & ;2 & 2 & $22^{++}$ & 3 & 2 & $22^{+}$ & $2^{\prime} 1$ & & $2-$ & 3; & 2 \\
\hline RL6008 & 17 & 21 & 3 & 3-1 & 3 & 1 & $\overline{1}$ & 3-1 & 3 & 3 & 3 & $3-1$ & 3 & 233 & $23-$ & 23 & $\overline{32}$ & 3 & 3 & $3-;$ \\
\hline RL6009 & 18 & $33^{=}$ & 2 & 23 & 3 & 3 & $23-$ & 1 & $; 1$ & 32 & $33-$ & 32 & 3 & $3-$ & 21 & $33^{-}$ & 32 & 3 & 2 & $3-;$ \\
\hline RL6040 & 19 & & ; & ; & 0 & 0 ; & 0 & ; & 0 & ; & ; & ; & 0 & 0 & ; & 0 & 0 & 0 & 0 & 0 \\
\hline CS-AXM7A & 20 & 3 & $; 1$ & 3 & $; \mathrm{N}$ & 3 & 3 & ; $1 \mathrm{~N}$ & $; 1 \mathrm{~N} 3$ & 3 & ; $1 \mathrm{~N}$ & iN & 3 & ;iN & ;N & $; 1 \mathrm{~N}$ & ;iN & 3 & ;1N & $23^{-} \mathrm{N}$ \\
\hline RL6043 & 21 & $23^{=}$ & 12 & $23^{\overline{ }}$ & $; 1$ & 2 & 1 & $; 1$ & $; 12$ & 3 & 2 & $; 2^{+}$ & 32 & $; 1$ & $1-;$ & $; 1$ & 12 & 2 & $; 1$ & 3 \\
\hline RL6012 & 23 & 2 & $; 1$ & 3 & 3 & 3 & 3 & 3 & $; 13$ & $; 1$ & 32 & 3 & 2 & 3 & 3 & 3 & 3 & 3 & 3 & $3^{+}$ \\
\hline PF869003 & 24 & $; 1$ & $; 1$ & $; 2$ & $;-2$ & $2-$ & $; 1$ & $; 1$ & 3 & 3 & $;-2$ & $; 2-$ & 2 & $; 1$ & $; 1$ & $; 2$ & $;-2$ & $; 1$ & $; 1$ & $3^{+}$ \\
\hline Sel. s/a Transec & $25 ?$ & & $; 1$ & $; 1 \mathrm{C}$ & ;C & $; 1$ & 3 & 3 & $; 1 \mathrm{C}$ & ; & 1 & ; & ;C & 3 & & 3 & & $3^{-}$ & ; & $; 12$ \\
\hline Sel. c/a Transec & $25 ?$ & $;-3$ & $; 2$ & $1-3$ & ;1N & $;-3$ & ; & ; & $;-3=$ & $; 1$ & $3-;$ & $;-3$ & $;-2$ & 1 & $3-;$ & $; 2$ & ;2 & $; 1$ & 2 & $;-2$ \\
\hline Thatcher $L r 26$ & 26 & & $; 1$ & ; & $3-$ & 32 & ; 1 & ;1 & $; 1$ & $; 1$ & $; 1$ & $;$ & $; 1$ & 3 & $33-$ & $; 1$ & $\frac{2}{1}$ & ; & ; & 3 \\
\hline CS Hope $3 B^{d}$ & $27+31$ & & 3 & $1-3$ & $3-;$ & $;-3$ & $3-;$ & $1-3$ & 3 & 3 & 3 & $;-3$ & 3 & $;-3$ & 3 & $; 2$ & $;-2$ & 3 & 3 & 3 \\
\hline Gatcher & $27+31$ & & 3 & 3 & $3-;$ & $; 2$ & 32 & $;-3$ & $; 1$ & 3 & 3 & $; 1$ & $;-3$ & $2,23^{-}$ & $; 1$ & & $; 1$ & 3 & $; 1$ & $3-;$ \\
\hline RL6049 & 30 & $23^{\prime}$ & $; 1$ & $33-$ & 12 & 32 & 3 & 32 & 3 & $; 2$ & 3 & $33-$ & $; 2$ & 2 & 3 & $\overline{3}$ & 32 & $23^{-}$ & 3 & 3 \\
\hline RL6057 & 33 & $33^{-}$ & $; 2$ & 3 & $2^{=}$ & 3 & 21 & 2 & 2 & 231 & 2 & $23^{=}$ & $33^{=}$ & $22^{+}$ & 2 & $23^{=}$ & $2^{+}$ & $2^{+}$ & $; 1$ & 32 \\
\hline RL6058 & 34 & 3 & 32 & 3 & $23^{=}$ & 3 & $33^{-}$ & 3 & $3++$ & 3 & 3 & 3 & 3 & 3 & 3 & 3 & 3 & $3^{-}$ & 3 & 3 \\
\hline RL6050 & $34+T 3$ & & 32 & 3 & 32 & 3 & $33^{-}$ & 3 & 3 & $3-;$ & 3 & 3 & 3 & 3 & 3 & $33^{-}$ & $33^{-}$ & $2 ; 3^{=}$ & $3-3=$ & 3 \\
\hline Thatcher $L r T 2$ & $T 2(34)$ & & & 3 & $3-$ & 3 & 3 & 3 & $3+$ & 3 & 3 & 3 & 3 & 3 & $3-1$ & 3 & 3 & 3 & 3 & $3^{+}$ \\
\hline
\end{tabular}

*: Citados em Roelfs et al. (1992). O tipo de infecção que antecede outro(s) é o prevalecente 0;12 (resistente) 34 (suscetível) e X (reação heterogênea). Os sinais - (menos) e + (mais) expressam graus de intensidade da reação.

$\mathrm{C}$ (clorose) $\mathrm{N}(\mathrm{Necrose})$

Denominação pelo sistema norte-americano (Long \& Kolmer, 1989). ${ }^{2}$ :Denominação pelo sistema nacional

: Ausência da informação. ,:Separa plantas com reações diferentes. -: Indica variação entre a reação que antecede e a que sucede o hífen.

a: Para as raças NBG/GR, SBJ/LQ, NBK/MR, MBK/ML, SDJ/QR, LLQ/HQ, MBR/RL E SBJ/BR, em vez de RL6003, RL6007, RL6004, RL6005 e RL6043 foram utilizadas linhagens provenientes do retrocruzamento destas com a cultivar IAC 5 -

Maringá.

b: Axminster c : Seleção de Transec sem arista (s/a) e seleção de Transec com arista (c/a). Transec possui $L r 25$

d: Gatcher $(\operatorname{Lr} 27+31)$ pode ter também Lr10 (Singh \& Rajaram, 1991) 
postulação, pode-se usar a análise genética para conferi-la. A postulação deve, ao menos, indicar quando não é preciso efetuar outros estudos (Roelfs et al., 1992).

\section{RESULTADOS E DISCUSSÃO}

Os tipos de infecção dos genótipos brasileiros aos isolados de $P$. triticina e a postulação dos genes de resistência encontram-se nas Tabelas 3 e 4, respectivamente.

O gene Lr10 está presente em muitos dos genótipos brasileiros analisados. Conforme McIntoch et al. (1995b), este gene, não amplamente efetivo sozinho, confere resistência em muitos locais, quando em combinações.

As cultivares OCEPAR 21, IAPAR 17 - Caete, IAPAR 6 - Tapejara apresentaram padrão de reação similar ao da monogênica $\operatorname{Lr} 10$. Trigo 'BR 18' além de $\operatorname{Lr} 10$ e outro(s) gene(s) não identificado(s), possui Lr13, detectado, também, com outras metodologias (Sousa, 1996; Zoldan et al., 2000). Trigo 'BR 18' tem sido considerado Alondra Sib, o que indicaria a presença de Lr26 (McIntosh, 1975). Conforme os resultados obtidos, 'BR 18 ' não possui $L r 26$. Rosa Filho (1997) relatou a ausência da translocação $1 \mathrm{~B} / 1 \mathrm{R}$ e, provavelmente, de $L r 26$ em 'BR 18'. $L r 10$ e outro(s) gene(s) foram postulados em 'IAPAR 29'. Esta cultivar é 'Opata 85', que possui $\operatorname{Lrl0}$ e outro(s) gene(s), de acordo com Singh \& Rajaram (1991) e não é portadora de Lr26 (Sayre, et al., 1997). Lr10 foi identificado também em 'OC 9511', além do gene $\operatorname{Lr} 14 b$.

A cultivar Trigo 'BR 15', foi indicada com possível combinação para resistência $\operatorname{Lr} 10+\operatorname{Lr} 18+\operatorname{Lr} 23$, e ainda algum gene que confere certo grau de resistência à raça TDD/ RR. Em relação à 'PF 9099', postulou-se a presença dos genes $L r 10$ e $L r 13$, este de resistência em planta adulta detectado por Sousa (1996) e Zoldan et al. (2000), Lr26 e $\operatorname{Lr}(27+31)$. 'EMBRAPA 119' procede do mesmo cruzamento de 'PF 9099', sendo ambas descendentes de BR 35. A reação de 'PF 9099' e 'EMBRAPA 119' às raças foi semelhante. A resistência em 'EMBRAPA 119' foi provavelmente conferida por $\operatorname{Lr} 10, \operatorname{Lr} 17, \operatorname{Lr} 26$, e outro(s) gene(s). Além de outro(s) gene(s) não identificado(s), $L r 10$ e $L r 23$ parecem estar envolvidos na resistência de 'OCEPAR 16', apesar da desuniformidade em tipo de infecção produzido a várias raças.

Em 'OC 959' houve indicação da presença dos genes $L r 11, L r 24$ e $L r 26$. Kavkaz (Lr26) e Agent (Lr24) (McIntosh, 1975) são alguns de seus genitores. 'OC 959' era resistente a todas as raças conhecidas no Brasil até 1994, quando foi detectada pela primeira vez uma raça que tornou inefetiva a combinação $L r 24+L r 26$, entre outras.

'PF 91450' e 'FUNDACEP 29' têm alguns genes de resistência similares, inclusive Lr16 (Buckbuck) (Singh \& Rajaram, 1991) não detectados nos outros genótipos.

Nas cultivares 'COODETEC 101' e 'Manitoba 97', foram identificados, respectivamente, os genes $\operatorname{Lr} 13, \mathrm{Lr} 14 \mathrm{~b}$, $L r 23$ e $L r 13, \operatorname{Lr} 23, \operatorname{Lr}(27+31)$. Possivelmente outro(s) gene(s) diferente(s) dos analisados deve(m) estar envolvidos na resistência de ambos os genótipos.

Em relação a 'IAPAR 46', postulou-se a presença dos genes $L r 13$ e Lr26. Alondra ( $L r 26$ ) é um dos seus genitores.

'RS 1 - Fênix' apresentou padrão de reação semelhante ao conferido pela combinação $L r 14 b+L r 23$ e gene(s) não identificado(s).

Duas cultivares demostraram possuir a combinação $L r 17+L r 23$, 'Panda' e 'OCEPAR 15'. Nesta foi postulado também Lr26 (Kavkaz) e em 'Panda', no mínimo, outro gene $L r$.

'EMBRAPA 16' e 'EMBRAPA 52' apresentaram o mesmo padrão de resistência, evidenciando a presença do gene Lr24, provavelmente do genitor 'Amigo' (The et al., 1992), além de $L r 1$, e de outro(s) gene(s). Nessas cultivares, o gene Lr13 foi relatado por Sousa \& Barcellos (1999b). No Trigo 'BR 38' também foi postulada a presença de $L r 1$ e $L r 24$ e segundo Sousa (1996), Lr13. Nessa cultivar a origem de Lr24 é provavelmente 'Agent'.

'EMBRAPA 120' e 'PF 9293' possuem a mesma origem e apresentaram o mesmo padrão de reação, que indicou ser a resistência conferida pelos genes $L r 23$ e $L r 24$, além de outro(s) gene(s). 'EMBRAPA 15' e 'EMBRAPA 27' também apresentaram reação semelhante e, conseqüentemente a mesma combinação para a resistência, $L r 23$ e $L r 24$, e outro(s). A combinação $L r 23$ e $L r 24$ também foi postulada na cultivar OR 1, que além destes talvez possua $L r 27+L r 31$ e Lr30. Estas cultivares e 'EMBRAPA 24' tornaram-se suscetíveis quando, em 1994, a raça MFT/KS que tornou ineficientes as combinações para a resistência $L r 23+L r 24$ e $L r 24+L r 26$.

Na cultivar EMBRAPA 24, o gene Lr24 (Tifton) (Barcellos, 1991) foi postulado juntamente com Lr26 e, outro(s) gene(s) diferente(s) dos analisados. Lr24 foi identificado em 'RS 8 - Westphalen'. A cultivar foi mais resistente que a monogênica para este gene, com relação a algumas raças, o que indicou a presença de outro(s) gene(s) não analisado(s).

O gene $L r 26$ foi postulado em 'EMBRAPA 40'. Os tipos de infecção conferidos por $L r 23$ às raças avaliadas permitiram indicar a possibilidade deste gene estar também na constituição genética de 'EMBRAPA 40'. A freqüente identificação de Lr26 em genótipos brasileiros é devido, provavelmente, à ascendência de 'Alondra' e 'Veery Sib' $(L r 13+L r 26$ ou $L r 26+L r 23)$ (Singh \& Rajaram, 1991). 'OCEPAR 18' e 'IAPAR 28', ambas 'Veery Sib' tendo como antecedente genético 'Kavkaz' ( $L r 26)$ apresentaram padrão de reação semelhante ao da monogênica para $L r 26$. Os resultados suportam, ainda, a possível presença de $L r 1$ provavelmente herdado de 'Bluebird' (Singh \& Rajaram, 1991) e Lr23. Sayre et al. (1997) identificaram a translocação 1B/1R (Lr26) em 'Veery'.

O gene $L r 26$ foi também identificado em 'IAPAR 78', descendente de 'Veery', bem como em 'OCEPAR 22', embora esta apresente resistência maior do que $L r 26$ para as raças $\mathrm{MCG} / \mathrm{RS}$ e LFG/MS, evidenciando a presença de mais algum(s) gene(s). Ambas as cultivares podem possuir 
TABELA 3 - Tipos de infecção* em plântulas de trigo (Triticum aestivum) exibidos por cultivares e linhagens brasileiras quando testadas a 22 raças de Puccinia triticina ${ }^{I}$

\begin{tabular}{|c|c|c|c|c|c|c|c|c|c|c|c|c|c|c|c|c|c|c|c|}
\hline \multirow{2}{*}{$\begin{array}{l}\text { CULTIVAR E } \\
\text { LINHAGEM }\end{array}$} & \multicolumn{19}{|c|}{ RAÇAS DE Puccinia triticina } \\
\hline & $\begin{array}{c}\text { NBG/ } \\
\text { GR/ }\end{array}$ & $\begin{array}{c}\text { SBJ/ } \\
\text { LQ }\end{array}$ & $\begin{array}{l}\text { NBK/ } \\
\text { MR }\end{array}$ & $\begin{array}{l}\text { LCJ// } \\
\text { RS }\end{array}$ & $\begin{array}{c}\mathrm{NCH} / / \\
\text { TR/ }\end{array}$ & $\begin{array}{c}\text { MBR/ } \\
\text { MR }\end{array}$ & $\begin{array}{c}\mathbf{M B K} / \\
\mathbf{M L}\end{array}$ & $\begin{array}{c}\text { TDT/ } / \\
\text { BL }\end{array}$ & $\begin{array}{c}\text { SDJ// } \\
\text { QR }\end{array}$ & $\begin{array}{l}\text { CBT/ } \\
\text { HQ }\end{array}$ & $\begin{array}{l}\text { LLK/ } / \\
\text { HQ }\end{array}$ & $\begin{array}{c}\text { HGJJ/ } \\
\text { JR }\end{array}$ & $\begin{array}{c}\text { MCG/ } \\
\text { RS }\end{array}$ & $\begin{array}{l}\text { MCR/ } \\
\text { CS }\end{array}$ & $\begin{array}{c}\text { MBR/ } / \\
\text { RL }\end{array}$ & $\begin{array}{c}\text { SLK/ } \\
\text { HQ }\end{array}$ & $\begin{array}{l}\text { TBJJ/ } \\
\text { RR }\end{array}$ & $\begin{array}{c}\text { CGT/ } \\
\text { CQQ }\end{array}$ & $\begin{array}{c}\text { MFT/ } / \\
\text { KS }\end{array}$ \\
\hline ANAHUAC & & 3 & & $;-2$ & & & $23^{=}$ & & & $; 1 \mathrm{C}$ & $; \mathrm{C}$ & $; 1$ & $; 1$ & $; 1$ & & & & & $;$ \\
\hline CEP 11 & ;1 & ;1 & ; & 3 & 23 & ;2 & $; 1$ & ; 1 & ;1 & 1 & 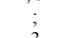 & ;1 & $; 1$ & ;1 & $3 ;$ & ; & 3 & 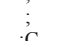 & $\vdots$ \\
\hline CEP 14 & ;1 & ;1 & 0 & ; & 2 & ; & $;$ & ; & $; 1$ & ;1 & 3 & ; & ;12 & ;1 & 0 & 3 & 2 & ;C & ;1 \\
\hline CEP 24 & & ; & ; & ; & $; 13$ & ; & ; & 0 & ; & 0 & ; & ; & & ; & ; & ;1 & ; & 0 & \\
\hline CEP 27 & ;1 & & ;1 & 0 & ; & 0 & ;1 & $0 ; 1$ & & 0 & $;-2$ & ; & 0 & ; & 0 & ;1 & 0 & 0 & 0 \\
\hline EMBRAPA 119 & $\vdots$ & $\vdots$ & $;$ & $3-;$ & $;-2$ & $\vdots$ & 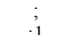 & $; 1$ & ;1 & 0 & 0 & ; & ;1 & & ; & 0 & 0 & & \\
\hline EMBRAPA 120 & ;1 & ;1 & $; 1$ & $;, ;-3$ & $;-1$ & 0 & $; 1$ & ;1C & ;1 & ; & $; 1$ & ;1 & $; 1$ & $; 1$ & ;1 & ;1 & ; & ;1 & 3 \\
\hline $\begin{array}{l}\text { EMBRAPA } 15 \\
\end{array}$ & $; 1$ & $;$ & $; 1$ & $; 1$ & $;-3$ & 1 & $; 1$ & $; 1$ & $;$ & $; 1$ & $;-2$ & $; 1$ & $; 1$ & 1 & $; 1$ & ;1 & $; 1$ & ;1 & ${ }_{3^{+}}$ \\
\hline $\begin{array}{l}\text { EMBRAPA } 16 \\
\text { EMBRAPA } 24\end{array}$ & ; & ; & $; 1$ & $;$ & $i_{10}^{; 1}$ & $\begin{array}{l}0 \\
0\end{array}$ & $; 1$ & $3^{3+1}$ & 3 & $; 1$ & 2 & ; $1 \mathrm{C}$ & $; 1$ & 1 & $; 1$ & ;1 & $\dot{0}$ & $\begin{array}{l}0 ; \\
0 ;\end{array}$ & $3^{3^{+}}$ \\
\hline $\begin{array}{l}\text { EMBRAPA } 24 \\
\text { EMBRAPA } 27\end{array}$ & $\vdots$ & $\vdots$ & $;$ & 0 & ${ }_{;-2^{+}}^{1 \mathrm{C}}$ & $\begin{array}{l}0 \\
; 1\end{array}$ & $\vdots 1$ & $; 1$ & ;1 & $\vdots$ & $\vdots$ & 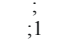 & $\vdots$ & $;_{1}^{\prime 1}$ & 0 & $\begin{array}{l}0 ; \\
: 1\end{array}$ & $\begin{array}{l}0 ; \\
: 1\end{array}$ & $\begin{array}{l}0 ; \\
0 ; 1\end{array}$ & $\begin{array}{l}3,3 ; \\
3\end{array}$ \\
\hline $\begin{array}{l}\text { EMBRAPA } 27 \\
\text { EMBRAPA } 40\end{array}$ & $;$ & $\therefore 1$ & & $3,32 \mathrm{z}$ & 3 & : & ; & :? & ;! & & ; $;$ & :? & 32 & $\frac{1}{3}$ & $\therefore \mathrm{C}$ & ic & ; & & 3 \\
\hline EMBRAPA 49 & $\therefore$ & ;1 & $;$ & ;1 & $3-;$ & ; & ; & ;1 & $\vdots$ & $;$ & $;$ & ;1 & $; 1$ & 3 & $;$ & ;1C & 0 & $\vdots$ & 3 \\
\hline EMBRAPA 52 & ;iN & 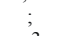 & $; 1$ & $; 1$ & ;1C & $;$ & $; 1$ & 3 & 3 & $; 1$ & ;1 & $; 1$ & $; 1$ & ;1 & ; & $; 1 \mathrm{C}$ & $;$ & ; & 3 \\
\hline FRONTANA & $3 ; 1$ & $;-3$ & $3 ; 1$ & $3-;$ & 3 & $3-1$ & 3 & ;1 & $;-3$ & $3 ;$ & $;-3$ & $3-;$ & $3-;$ & $3-;$ & 31 & $3-;$ & $;-3$ & $;-3$ & 32 \\
\hline FUNDACEP 29 & 2 & $; 2$ & 2 & 1 & $2^{++}$ & 2 & 1 & $2-$ & $; 1$ & $2^{2-}$ & $; 1$ & 3-; & 2 & $2-;$ & $; 1$ & 2 & $;-2^{2}$ & 3 & $2^{-=}$ \\
\hline IAC-5 MARINGÁ & 3 & 3 & 3 & 32 & 3 & 31 & 3 & 3 & 3 & $3^{+}$ & 3 & 3 & 3 & 3 & 3 & 3 & 32 & 3 & 3 \\
\hline $\begin{array}{l}\text { IAPAR } 17 \\
\text { IAPAR } 28\end{array}$ & $\bar{\vdots}$ & $\overline{: 1}$ & 3. & $\begin{array}{l}3 \\
3 \\
-\end{array}$ & $\begin{array}{l}3 \\
3\end{array}$ & $33^{\circ}$ & $\bar{\xi}$ & $; 1$ & $\bar{\vdots}$ & $; 11$ & ;1 & $; 1$ & $\begin{array}{l}3 \\
3\end{array}$ & 0 & $\overline{0}$ & $; 10$ & 3 & : ic & ;1 \\
\hline $\begin{array}{l}\text { IAPAR } 28 \\
\text { IAPAR } 29\end{array}$ & $\vdots 1$ & $3=$ & 3 & $3-;$ & 3 & 3 & 3 & ;1 & $\begin{array}{c}\vdots \\
;-3\end{array}$ & ;1 & $\overline{; 1}$ & ;1 & $; ;-3^{3}$ & 3 & 3-1 & ; & $3-;$ & 0 & $\overline{; 2}$ \\
\hline IAPAR 46 & & ;1 & ; & 32 & 3 & ;C & ; & ;1 & $; 1$ & $; 1$ & & ;1 & 3 & 32 & $; 1$ & ;1 & $;$ & ;C & 32 \\
\hline IAPAR 53 & ;1 & & & $; 1$ & ; & 32 & $3-;$ & 3 & . & 3 & ;1 & 3 & $2^{++}$ & 33 & $;-3$ & ;1 & 3 & 3,$3 ;$ & 3 \\
\hline IAPAR 6 & $;-3^{-}$ & 3 & 3 & 32 & 3 & 32 & 3 & ;1 & $3-;$ & ;1 & ; & ;1 & 3 & ; & 3 & $; 1$ & 3 & 0 & 2 \\
\hline IAPAR 60 & $; 1$ & 3 & 3 & $;-3$ & 3 & $33^{\circ}$ & 3 & ; & $;-3$ & & ;1 & ;1 & ;123 & ;1 & $1-3$ & $; 1$ & 32 & 0 & \\
\hline $\begin{array}{l}\text { IAPAR } 78 \\
\text { IAPAR } 84 \text { (PG 9377) }\end{array}$ & $;$ & $\vdots$ & $;$ & 3 & 322 & ; & & $; 1$ & $;$ & 0 & ; & ; & $2^{2+}$ & $3^{=}$ & ; & $\vdots$ & ; & ; & 3 \\
\hline $\begin{array}{l}\text { IAPAR 84 (PG 9337) } \\
\text { MANITOBA } 97\end{array}$ & 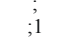 & $\vdots 1$ & $\begin{array}{c}\vdots \\
;-3\end{array}$ & $; 1$ & ;C; & $\vdots 1$ & 3-; & $; 12$ & $\vdots$ & $\dot{3}$ & $\begin{array}{c}\vdots \\
;-3\end{array}$ & 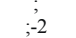 & ;123 & 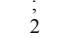 & $; ;-2^{=}$ & $\begin{array}{l}0 ; \\
21 ;\end{array}$ & $\begin{array}{c}\vdots \\
3,32\end{array}$ & 3 & $\vdots$ \\
\hline OC 939 & $; 1$ & $; 1$ & 23 & $2, ;-3=$ & $;-2$ & $2^{=}$ & $1-3$ & $; 1$ & $; 1$ & $3^{=}$ & 0 & $; 1 \mathrm{C}$ & 2 & $1-3$ & $; 1$ & 2 & $3-;$ & 3 & 2 \\
\hline OC 9511 & ;1 & $;-3$ & 3 & 2 & 3 & 3 & ; & ;1 & ;2 & $; 1$ & ;1 & $; 1$ & 3 & ; & ;3 & ; & $3-;$ & 0 & \\
\hline OC 959 & ; & ; & ; & ; & ;1C & ; & ; & ; 1 & ; & ; & ; & ;1 & $; 1$ & ; & ; & $;$ & $;$ & 0 & 3 \\
\hline OCEPAR 10 & ; & ; & ; & ; & $; 2 \mathrm{C}$ & ; & & ;1 & & 0 & ; & ; & 23,3 & 32 & ; & ;1 & $;$ & 0 & $\mathrm{x}$ \\
\hline OCEPAR 14 & ; & ; & ;1 & $; 1$ & $; 1$ & 3 & 3 & 0 & 0 & ;1 & $;$ & $;$ & 3 & $; 1$ & 3 & 0 & $3-1$ & ; & ;1 \\
\hline & & & $\therefore$ & 3,32 & ;2 & & ; & & $\Omega^{\prime}$ & $; 1$ & & & $22^{+}$ & 33 & & $; 1 \mathrm{C}$ & $;$ & ;C & 3 \\
\hline $\begin{array}{l}\text { OCEPAR } 16 \\
\text { OCEPAR } 18\end{array}$ & $;-3,3$ & ;2 & 3 & $\begin{array}{l}3-2 \\
33^{2}=\end{array}$ & 3 & $\begin{array}{r}3 \\
\cdot 1\end{array}$ & $\begin{array}{r}3 \\
\cdot 1\end{array}$ & $; 1,3,2$ & $; 2, ;, ; ;-3$ & $\stackrel{;}{:}$ & $; 1,3$ & $; 1,3$ & 3 & $\begin{array}{l}3, ; 1 \\
3\end{array}$ & 3 &,$;, 3$ & $3-;$ & $\begin{array}{l}0 ; \\
: 1 \mathrm{C}\end{array}$ & $; 1,3,3,-;$ \\
\hline OCEPAR 21 & $; 2^{\prime}$ & 3 & 3 & 3 & 3 & $\frac{1}{3}$ & $\frac{1}{3}$ & $\begin{array}{l}; 1 \\
; 1\end{array}$ & 3 & $; 1$ & $; 1$ & $\vdots 1$ & 3- & ; $1 \mathrm{C}$ & $\frac{1}{3}$ & $\begin{array}{l}; 1 \\
; 1\end{array}$ & $\vdots$ & ;IC & $\begin{array}{l}3 \\
2\end{array}$ \\
\hline OCEPAR 22 & & ; & ; & 3 & 3 & ; & ; & ;1 & & ;1C & 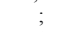 & ; $1 \mathrm{C}$ & $2^{+}$ & 3 & ; & $; 1$ & 0 & ;C & 3 \\
\hline EPAR 23 & $; 1$ & & & ;12 & ;1C & ; & ; & ; & 0 & 0 & 2 & & ;1 & & & 0 & & 0 & ; \\
\hline & ;1 & ;1 & ;1 & $; 1$ & $; 1$ & $; 1$ & & $; 1$ & & $; 1$ & $; 2$ & ;1 & ;1 & ; & ;1 & $; 1 \mathrm{C}$ & ;1 & 0 & $3^{+}$ \\
\hline DA & $; 2$ & 1 & $; 2$ & $3-;$ & $;-3$ & $; 2^{=}$ & $1-3^{-}$ & $; 1 \mathrm{C}$ & ;1 & $2^{++}$ & 23 & ;2 & 2 & $23^{-}$ & 2 & 2 & 3- & 3 & $\mathrm{X}$ \\
\hline $\begin{array}{l}\text { PELADINHO } \\
\text { PF } 9099\end{array}$ & 3 & 3 & 3 & 32 & 3 & 3 & 3 & 3 & 3 & 2 & 3 & 3 & 3 & 2 & 3 & $33^{-}$ & 3 & 3. & 3 \\
\hline $\begin{array}{l}\text { PF 9091450 } \\
\text { PF } 9140\end{array}$ & 2 & $\vdots 1$ & 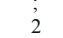 & $\frac{;-3}{2}$ & $\begin{array}{l}2 \\
2\end{array}$ & i & $\vdots$ & $\begin{array}{l}0 ;= \\
1,1-3^{-}\end{array}$ & $; 1$ & $\dot{\vdots} 2^{+} 2$ & 3 & $\begin{array}{c}\vdots \\
3-3\end{array}$ & $;_{2}^{1}$ & $\dot{\vdots}$ & $i^{2}=$ & 2 & $\therefore$ & 3: & \\
\hline PF 9293 & & $; 1$ & $; 1$ & 0 & $; 1$ & 1 & $; 1$ & $; 12$ & $; 1$ & $; 1$ & $; 1$ & $; 1$ & $; 1$ & 1 & $; 1$ & $; 1$ & ; & $; 1$ & 3 \\
\hline RS 1 & 12 & $; 1$ & 3 & $;-3^{-}$ & 3 & 2 & $1-3$ & $; 1$ & $; 1$ & $2^{+}$ & 2 & $; 1$ & $;-3$ & 3 & $23^{=}$ & 32 & 2 & 3 & 3 \\
\hline RS-8 & ;1 & $; 1$ & ;1 & & 2 & 1 & $; 1$ & 3 & 3 & $;-2$ & $; 2^{=}$ & 2 & $; 1$ & ;1 & $; 1$ & $; 1$ & 0 & ;1 & 3 \\
\hline RUBI (ORL 9285) & ; & ; & ;1 & 0 & ; & 1 & $; 1$ & $; 1 \mathrm{C}$ & 0 & ; & & & $; 1$ & & $; 1$ & 0 & & ; & ;1 \\
\hline SA 9458 & & & & $; 1$ & & & & $; 1$ & 0 & $;$ & 0 & $; 1 \mathrm{C}$ & $2=$ & 3 & ;1C & & 0 & & 3 \\
\hline & 3 & 3 & 3 & 3 & 3 & 3 & 3 & 4 & 3 & $3^{+}$ & 3 & $3+$ & $3+$ & 3 & 3 & 3 & 3 & 3 & $3+$ \\
\hline TRIGO BR 15 & $; 1$ & & 3 & $3-;$ & 3 & $23^{\circ}$ & & ; & $; 1$ & $; 1$ & ;1 & $; 1$ & 3 & $; 1$ & 3 & ;1 & 3 & & ; \\
\hline TRIGO BR 18 & ; & $23^{-}$ & 3 & 3 & 3 & $23^{\circ}$ & 3 & $;$ & ;1 & $; 1$ & ; & ;N & 3 & $; 1$ & 3 & ; & 3 & 0 & \\
\hline TRIGO BR 23 & $;$ & ; & $;$ & $;-3$ & $;-2^{-}$ & ; & $; 1$ & 0 & ; & $; 1$ & $;$ & $;$ & $23^{-}$ & $3-;$ & $;$ & $;$ & $;$ & $;$ & $32 ;$ \\
\hline $\begin{array}{l}\text { TRIGO BR } 32 \\
\text { TRIGO BR } 32\end{array}$ & ; & $;$ & ; & $; 1$ & 23 & $\dot{0}$ & $; 1$ & $\dot{3}$ & ; & ;C & $;$ & $\vdots$ & $; 1$ & 3. & $\vdots$ & $; 1$ & ; & ;C & 3 \\
\hline $\begin{array}{l}\text { TRIGO BR } 35 \\
\text { TRIGO BR } 38\end{array}$ & 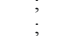 & $\vdots ;$ & $\vdots 1$ & $;-5$ & $\begin{array}{l}3 \\
; 1\end{array}$ & $\begin{array}{l}0 ; \\
; 1\end{array}$ & $;$ & $; 12$ & 3-; & ;1 & $;$ & $;$ & $\begin{array}{l}3 \\
; 1\end{array}$ & $\begin{array}{l}3 \\
; 1\end{array}$ & ;i & $; 1$ & $\vdots$ & $; 0$ & $\begin{array}{l}3 \\
3-;\end{array}$ \\
\hline
\end{tabular}

": Citados em Roelfs et al. (1992). O tipo de infecção que antecede outro(s) é o prevalecente $0 ; 12$ (resistente) 34 (suscetível) e X (reação heterogênea). Os sinais - (menos) e + (mais) expressam graus de intensidade da reação. C (clorose) N (Necrose)

Denominaç̃o pelo sistema norte-americano (Long \& Kolmer, 1989) 
TABELA 4 - Postulação dos genes $L r$ de resistência à ferrugem da folha em trigo (Triticum aestivum)

\begin{tabular}{|c|c|}
\hline GENÓTIPO & GENE $L r$ POSTULADO \\
\hline EMBRAPA 16 & $1 \underline{24}+$ \\
\hline EMBRAPA 52 & $1 \underline{24}+$ \\
\hline TRIGO BR 38 & $1 \frac{24}{24}+$ \\
\hline OCEPAR 21 & $\frac{10}{10}$ \\
\hline IAPAR 17 - CAETÉ & $\underline{10}$ \\
\hline IAPAR 6 - TAPEJARA & 10 \\
\hline IAPAR 29 & $10+$ \\
\hline TRIGO BR 18 & $1013+$ \\
\hline CEP 11 & $\begin{array}{lllll}10 & 13 & 18 & 23 & +\end{array}$ \\
\hline OC 9511 & $1014 b+$ \\
\hline EMBRAPA 119 & $\underline{10} \quad \underline{17} \underline{26}+$ \\
\hline ANAHUAC 75 & 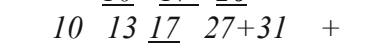 \\
\hline PF 9099 & 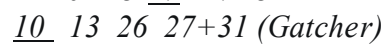 \\
\hline IAPAR 60 & $10 \quad 27+31+$ \\
\hline TRIGO BR 15 & $101823+$ \\
\hline OCEPAR 16 & $1023+$ \\
\hline OC 959 & $\overline{11} \quad \underline{24} \underline{26}$ \\
\hline PF 91450 & $13 \quad 14 a \quad 14 b \quad 16$ \\
\hline FUNDACEP 29 (CEP 9019) & $13 \quad \overline{14 a} \quad 16 \quad \overline{30}$ \\
\hline COODETEC 101 (OC 939) & $\underline{13} 14 b 23+$ \\
\hline MANITOBA 97 & $13 \underline{23} \quad 27+31+$ \\
\hline IAPAR 46 & $\underline{13} 26$ \\
\hline RS 1 - FÊNIX & $14 \bar{b} \underline{23}+$ \\
\hline PANDA & $17 \underline{23}+$ \\
\hline OCEPAR 15 & $17 \quad 23 \quad 26$ \\
\hline TRIGO BR 35 & 2326 \\
\hline EMBRAPA 120 & $\underline{23} \underline{24}+$ \\
\hline PF 9293 & $\overline{23} \overline{24}+$ \\
\hline EMBRAPA 15 & $23 \underline{24}+$ \\
\hline OR 1 & $23 \quad \underline{24} \quad \overline{27}+31 \quad 30$ \\
\hline EMBRAPA 40 & 2326 \\
\hline EMBRAPA 27 & $\underline{23} \underline{24}+$ \\
\hline RS 8 - WESTPHALEN & $24+$ \\
\hline EMBRAPA 24 & $\underline{24} \underline{26}+$ \\
\hline IAPAR 28 - IGAPÓ & $\underline{\underline{26}}$ \\
\hline IAPAR 78 & $1 \quad \overline{23} \quad 26$ \\
\hline OCEPAR 18 & $-\frac{26}{26}$ \\
\hline OCEPAR 22 & $123 \underline{26}+$ \\
\hline TRIGO BR 23 & $262 \overline{7}+31(\overline{\text { Gatcher })} T 2$ \\
\hline RUBI (ORL 9285) & $\underline{17} 23 \quad 24+*$ \\
\hline OCEPAR 23 & $\begin{array}{lll}3 & \overline{10} \quad \overline{24} \quad 26\end{array}$ \\
\hline OCEPAR 14 & $310+$ \\
\hline OCEPAR 10 - GARÇA & $3 \quad 17 \quad 26$ \\
\hline TRIGO BR 32 & $33 k \bar{a} \underline{26}+$ \\
\hline FRONTANA & $34+T 3 \overline{5+}$ \\
\hline IAPAR 53 & $3 b g+$ \\
\hline SA 9458 & $3 b g \quad 26 \quad 30$ \\
\hline EMBRAPA 49 & $3 k a \overline{26}+$ \\
\hline CEP 14 - TAPES & $\underline{9}$ \\
\hline CEP 24 - INDUSTRIAL & $910 \quad 24$ \\
\hline CEP 27 - MISSÕES & $9 \quad 10 \quad 24$ \\
\hline IAC 5 - MARINGÁ & NENHUM \\
\hline PELADINHO & NENHUM \\
\hline TOROPI & NENHUM \\
\hline IAPAR 84 (PG 9337) & $26 \quad 27+31 *$ \\
\hline
\end{tabular}

+ Outro(s) gene(s), provavelmente diferente(s) dos analisados deve(m) estar contribuindo para a resistência do genótipo;

* Resistente a todas as raças; Difícil quanto a postulação dos genes de resistência; Lr: postulação de acordo também com a genealogia. também $L r 1$ e $L r 23$. $L r 1$, em 'OCEPAR 22', talvez derive de Bluebird.

Em 'EMBRAPA 49' e em 'BR 32', as combinações $L r 26+L r 3 k a$ e $L r 26+L r 3 k a+L r 3$ foram detectadas, respectivamente, embora, também nessas cultivares outro(s) gene(s) não identificado(s) deva(m) estar contribuindo para a resistência. 'BR 32' descende de 'Alondra' ( $L r 26)$ e 'EMBRAPA 49', de 'BR 35'. Para essa cultivar postulou-se a presença do $L r 26$ e $L r 23$. Enquanto 'BR 35' deve possuir o gene de resistência de planta adulta $L r 34$ (necrose da ponta da folha) (Sousa \& Barcellos, 1999a), 'EMBRAPA 49' não parece ser portadora dos genes de resistência de planta adulta Lr23 e Lr34, segundo as necroses a eles associadas (Sousa \& Barcellos, 1999a; Sousa \& Barcellos, 1999b).

Para o Trigo 'BR 23' postulou-se a combinação dos genes para resistência $\operatorname{Lr} 26+\operatorname{Lr}(27+31)$ e $T 2 . \operatorname{Lr} 13$ (Sousa \& Barcellos, 1999b; Zoldan et al., 2000) e Lr34 (Sousa \& Barcellos 1999a) devem estar conferindo resistência em estádio de planta adulta. Trigo 'BR 23' e 'BR 35' possuem a translocação do centeio $(\operatorname{Lr} 26)$, segundo Rosa Filho (1997).

A resistência à maioria das raças da cultivar OCEPAR 23, foi atribuída à combinação dos genes $\operatorname{Lr} 26+\operatorname{Lr} 10$. A resistência às demais raças foi explicada pela presença também de $L r 24$ e $L r 3$. De acordo com o padrão de resistência avaliado, 'OCEPAR 14' provavelmente possua $L r 3, \operatorname{Lr} 10$ e outro(s) gene(s), enquanto que 'OCEPAR 10 - Garça', Lr3, Lr17 e Lr26. Conforme a reação devido à interação do patógeno com o gene $L r l$, é possível que este também esteja na constituição de 'OCEPAR 14' e 'OCEPAR 10'.

O gene $\mathrm{Lr} 3 b g$ foi postulado nas cultivares IAPAR 53 e SA 9458, em combinação com Lr26 e Lr30 nessa cultivar e com gene(s) adicional(is) não identificado(s) em 'IAPAR 53'.

'PG 9337' e 'ORL 9285', denominadas como cultivar, respectivamente 'IPR 84' e 'Rubi', foram resistentes a todas as raças e, portanto, difíceis quanto à postulação dos genes de resistência.

Em 'PG 9337', são genes prováveis para a resistência: Lr26, possivelmente derivado do genitor 'Alondra' e os genes $L r 27+L r 31$, de 'Anahuac' (Sing \& Rajaram, 1991) embora os padrões de resistência produzidos às raças suportem a indicação da presença de um dos alelos de $\operatorname{Lr} 2$, Lr3bg (ou alelo), Lr9, Lr10, Lr21, Lr23 e de Lr24. As monogênicas $L r 9, \operatorname{Lr} 19$ e $L r 21$ reagiram com mais resistência do que 'ORL $9285^{\prime}$, com relação à raça $\mathrm{TDD} / \mathrm{RR}$, indicando a inexistência destes genes na linhagem. A ausência de Lr19 é confirmada porque o genitor 'EMBRAPA 27' (PF 869107) que poderia possuir este gene é suscetível e monogênica para $\operatorname{Lr} 19$, resistente no Brasil. Por outro lado, 'Agent' (Lr24) está na constituição genética de 'EMBRAPA 27'. O outro genitor 'KLH 3450 C 3131' descende de 'Veery', origem provável de $L r 23$. Além dos genes $L r 23$ e Lr24, foi postulada a presença de $L r 17$ em 'ORL 9285', possivelmente herdado do ancestral 'Klein Lucero' (Roelfs et al., 1992) que está na origem de 'Klein Sendero', um dos genitores de 'KLH 3450 C 3131'. Com exceção de $\operatorname{Lr} 9$, $\operatorname{Lr} 19$ e $\operatorname{Lr} 21$, os genes analisados 
conferiram menos resistência do que a reação de 'ORL 9285'. 'ORL 9285' não deve possuir Lr34, conforme o marcador visual associado a esse gene, necrose da ponta da folha (Barcellos, comunicação pessoal). Lr26 também não deve estar na sua constituição, por não ter sido detectada a translocação de centeio 1B/1R (Rosa Filho, 1997). Considerando-se o tipo de infecção conferido pelo genes $L r$ e por 'ORL 9285', foi indicada a possível presença de $L r 17, L r 23, L r 24$ e ainda, $L \mathrm{r} 2 a, L r 3 b g$ e $L r 10$. Gene(s) adicional(is), provavelmente diferente(s) dos analisados, deve(m) existir em 'ORL 9285', para conferir a resistência.

Para 'EMBRAPA 120', 'OR 1' e 'PF 9293' outros genótipos descendentes de 'PF 869107 Sib’ (EMBRAPA 27), também se postulou a presença de $L r 23, L r 24$ e outro(s) gene(s).

A suscetibilidade das cultivares Peladinho, IAC 5Maringá e Toropi às raças indicou a inexistência de genes de resistência de plântula. 'IAC 5' apresenta necrose da ponta da folha, marcador visual do gene de resistência de planta adulta Lr34 (Sousa \& Barcellos, 1999a) evidenciada no campo. Na constituição genética desta cultivar está 'Frontana', que possui Lr34 (Dyck \& Samborski, 1982). Em 'Toropi', descendente de 'Frontana', dois genes recessivos, estritamente do tipo de planta adulta, foram detectados. Um destes genes de resistência, no mínimo, é diferente dos anteriormente descritos ( $L r 12,13,34$ e 22b) em T. aestivum, para resistência de planta adulta (Barcellos, 1994).

'Frontana,' cultivar de trigo brasileira, extensivamente usada como fonte internacional de resistência durável, segundo Roelfs et al. (1992), apresenta Lr13, Lr34, T3, e genes adicionais. 'Frontana', no presente estudo, foi mais resistente que a linhagem portadora de $L r 34+T 3$, indicando a presença de outro(s) gene(s) de resistência. Contudo, a monogênica para Lr13 apresentou mais resistência do que 'Frontana' para algumas raças, não sendo possível confirmar este gene de resistência de planta adulta em 'Frontana' pela metodologia de postulação de genes em plântulas.

$\mathrm{Na}$ cultivar Anahuac 75 foi identificada a seguinte combinação de genes: $\operatorname{Lr} 10+\operatorname{Lr} 13+\operatorname{Lr} 17+\operatorname{Lr}(27+31)$. A cultivar apresentou tipos de infecção mais baixo do que as linhagens com os genes $L r$ para algumas raças, indicando gene(s) adicional(is). $\operatorname{Lr} 13$ e $\operatorname{Lr} 17$ estão em sua constituição genética, derivados de 'Lerma Rojo 64' ou 'Norteño 67' = Inia F 66 "S" (Singh \& Rajaram, 1991). De acordo com a mesma referência, 'Anahuac 75 ' possui $\operatorname{Lr} 13, \operatorname{Lr} 17$, $L r 27+31$. Os autores haviam utilizado a cultivar Gatcher para postular $L r 27+31$ e esta possui, possivelmente também $L r 10$.

Em 'IAPAR 60' foi atribuída a presença da combinação $\operatorname{Lr} 10+(\operatorname{Lr} 27+31)$, além de outro(s) gene(s) de resistência. Sing \& Rajaram (1991), determinaram a presença de $L r 27+L r 31$ em 'Jupateco 73' e de Lr10 em 'Bluejay Sib', antecedentes de 'IAPAR 60'.

As cultivares CEP 24 e CEP 27 tornaram-se suscetíveis em 1997, quando uma raça até então desconhecida tornou ineficientes as combinações $\operatorname{Lr} 9+24, \operatorname{Lr} 9+26$ e $\operatorname{Lr} 9+10$, que conferiam resistência a todas as raças. Postulou-se que $\operatorname{Lr} 9$,
Lr10 e Lr24 estejam presentes nestas cultivares. A translocação 1B/1R não foi identificada em 'CEP 24' (Rosa Filho, 1997). 'CEP 14' apresentou padrão de reação semelhante ao da monogênica para $\operatorname{Lr} 9$. A cultivar descende de 'Arthur 71' que possui Lr9 (McIntoch et al, 1995). 'CEP 14' expressou menor nível de resistência para as raças $\mathrm{NCH} /$ TR, MCG/RS E TBJ/RR, do que a monogênica. Em 1986, 'CEP 14', que havia sido recomendada em 1985, tornou-se suscetível, sendo infetada por uma raça detectada pela primeira vez naquele ano, a qual tornou ineficiente a resistência que $\operatorname{Lr} 9$ conferia a todas as raças.

Em 'CEP 11' foi postulada a possível combinação para resistência $\operatorname{Lr} 10+\operatorname{Lr} 13+\operatorname{Lr} 18+\operatorname{Lr} 23$, embora esta não seja suficiente para conferir a resistência na cultivar. 'CEP 11 ' e seu genitor 'Hadden', foram resistentes, apresentando muita clorose, em condições de campo, por muitos anos.

Do grupo de genes que determina a resistência a uma raça específica, o gene Lr19 de Agropyrom elongatum (Host.) Beauv. era eficaz às raças do patógeno, em todo o mundo, mas utilizado em cultivares comerciais somente em área limitada. Lr19 está ligado a um fator que produz cor amarela na farinha (Roelfs et al., 1992). Huerta-Espino \& Singh (1994), no México, e Sibikeev et al. (1996), na Rússia, relataram virulência para este gene. No Brasil o gene Lr19 continua efetivo a todas as raças, não tendo sido detectado nos genótipos desta análise.

Os alelos de $L r 2$ e o gene $L r 20$, em T. aestivum, assim como Lr25 (Secale cereale L. 'Rosem'), Lr28 (Triticum speltoides Tausch), Lr29 (A. elongatum) e Lr21 e Lr32 [T. tauschii (Coss.) Schmal.] também não foram detectados nos genótipos brasileiros.

Os genes $\operatorname{Lr} 12$, $\operatorname{Lr} 15$ e $T 3$ conferiram suscetibilidade a todas as raças, podendo estar, portanto, segundo a metodologia deste estudo em qualquer dos genótipos, sem contribuir para resistência.

De acordo com McVey (1992), possivelmente alguns dos genes para resistência à ferrugem, não detectados, podem ter sido mascarados por outro gene ou genes que condicionaram o mesmo tipo de infecção ou mais resistência. Além disso, um gene pode ter sido erroneamente postulado, porque outro, desconhecido, presente no hospedeiro, apresentou o mesmo tipo de infecção ou mais resistência a um isolado do patógeno avirulento. Outra dificuldade desses testes consiste em não ser adequados para detectar a presença de genes que são efetivos somente no estádio de planta adulta, com o Lr34 e os genes de 'Toropi'.

Os genes mais freqüentemente encontrados nos genótipos brasileiros analisados foram: $\operatorname{Lr} 26$ (15.4\%), Lr23 (14,6\%), Lr10 (13,8\%), Lr24 (12,2\%). Os demais genes detectados, Lr1, Lr3, Lr3bg, Lr3ka, Lr9, Lr11, Lr14a, Lr14b, $\operatorname{Lr} 16, \operatorname{Lr} 17, \operatorname{Lr} 18, \operatorname{Lr} 27+\operatorname{Lr} 31$ e $L r 30$, ocorreram com freqüência inferior a $10 \%$ (Tabela 5 ).

Os dados obtidos levam a crer que genes distintos dos analisados estão contribuindo para a resistência das cultivares brasileiras, sendo necessário efetuar outros estudos para identificá-los. 
TABELA 5 - Freqüência de genes para a resistência à ferrugem da folha em genótipos brasileiros de trigo (Triticum aestivum)

\begin{tabular}{lc}
\hline \hline GENE $\boldsymbol{L} \boldsymbol{r}$ & OCORRENCIA NAS CULTIVARES \% \\
\hline 1 & 4,1 \\
3 & 3,25 \\
$3 \mathrm{bg}$ & 1,6 \\
$3 \mathrm{ka}$ & 1,6 \\
9 & 2,4 \\
10 & 13,8 \\
11 & 0,8 \\
13 & 7,3 \\
$14 a$ & 1,6 \\
$14 b$ & 3,25 \\
16 & 1,6 \\
17 & 4,9 \\
18 & 1,6 \\
23 & 14,6 \\
24 & 12,2 \\
26 & 15,4 \\
$27+31$ & 5,7 \\
30 & 2,4 \\
$34+T 3$ & 0,8 \\
$T 2$ & 0,8 \\
\hline
\end{tabular}

\section{REFERÊNCIAS BIBLIOGRÁFICAS}

BARCELLOS, A.L. Durable leaf rust resistance in wheat in Brazil. In: Saunders, D.A. (Ed.) Wheat for the non-traditional warm areas. México: CYMMYT, 1991. pp.462-465.

BARCELLOS, A.L. Genética da resistência de planta adulta à ferrugem da folha na cultivar brasileira de trigo Toropi (Triticum aestivum L. em. Thell). (Tese de Doutorado) Universidade Federal do Rio Grande do Sul, Porto Alegre, 1994.

DUBIN, H.J., JOHNSON, R. \& STUBBS, R.W. Postulated genes for resistance to stripe rust in selected CIMMYT and related wheats. Plant Disease 73:472-475. 1989.

DYCK, P.L. \& SAMBORSKI, D.J. The inheritance of resistance to Puccinia recondita in a group of common wheat cultivars. Canadian Journal of Genetics and Cytology 24:273-283. 1982.

FLOR, H.H. Host-parasite interaction in flax rust. Its genetics and other implications. Phytopathology 45:680-685. 1955.

HUERTA-ESPINO, J. \& SINGH, R.P. First report of virulence for wheat leaf rust resistance gene $\mathrm{Lr} 19$ in Mexico. Plant Disease 78:640. 1994.

KOLMER, J.A. \& DYCK, P.L. Gene expression in the Triticum aestivum-Puccinia recondita f. sp. tritici gene-for-gene system. Phytopathology 84:437-440. 1994.

LOEGERING, W.Q. Genetics of the pathogen-host association. In: Bushnell, W.R. \& Roelfs, A.P. (Eds.) The cereal rusts: origins, specificity, structure and physiology. Orlando: Academic Press, 1984. v.1, pp.131-164.

LONG, D.L. \& KOLMER, J.A. A North American System of Nomenclature for Puccinia recondita f. sp. tritici. Phytophatology 79:525-529. 1989.

McINTOSH, R.A. Catalogue of gene symbols for wheat Kansas State University and Canada Department of Agriculture. Annual Wheat Newsletter 11:32-45. 1975.
McINTOSH, R.A., FRIEBE, B., JIANG, J., THE, D. \& GILL, B.S. Cytogenetical studies in wheat XVI. Chromosome location of a new gene for resistance to leaf rust in a Japanese wheat Rye translocation line. Euphytica 82:141-147. 1995a.

McINTOSH, R.A., WELLINGS \& PARK, R.F. Wheat Rust: an atlas of resistance genes. University of Sydney, Australia, 1995b.

McVEY, D.V. Genes for rust resistance in International winter wheat Nurseries XII through XVII. Crop Science 32:891-895. 1992.

McVEY, D.V. \& LONG, D.L. Genes for leaf rust resistance in hard red wheat cultivars and parental lines. Crop Science 33:13731381. 1993.

MODAWI, R.S., BROWDER, L.E. \& HEYNE, E.G. The use of infection-type data to identify genes for low reaction to Puccinia recondita in several winter wheat cultivars. Crop Science 25:913. 1985.

PERSON, C. Gene-for-gene relationships in hosp: parasite systems. Canadian Journal of Botany 37:1101-1130. 1959.

RIZVI, S.S.A. \& BUCHENAU, G.W. Tentative identification and verification of genes for leaf rust resistance in wheat cultivars of South Dakota. Plant Disease 78:674-679. 1994.

ROELFS, A. P., SINGH, R. P. \& SAARI, E. E. Las royas del trigo: conceptos y métodos para el manejo de esas enfermedades. México: CIMMYT, 1992.

ROSA FILHO, O. Effect of the six glutenin loci on selected bread quality traits in wheat. (PhD Thesis). Oregon State University. Corvallis, Oregon, 1997.

SAYRE, K.D., RAJARAM, S. \& FISCHER. R.A. Yield potential progress in short bread wheat in northwest Mexico. Crop Science 37:36-42. 1997.

SIBIKEEV, S.N., KRUPNOV, V.A., VORONINA, S.A. \& ELESIN, V.A. First report of leaf rust pathotypes virulent to highly effective $L r$-genes transferred from Agropyron species to bread wheat. Plant Breeding 115:276-278. 1996.

SINGH, R.P. \& McINTOSH, R.A. Complementary genes for reaction to Puccinia recondita tritici in Triticum aestivum. II. Genetic and linkage studies. Canadian Journal of Genetics and Cytology 26:736-742. 1984.

SINGH, R.P., MUJEEB-KAZI A. \& HUERTA-ESPINO, J. Lr46: A gene conferring slow-rusting resistance to leaf rust in wheat. Phytopathology 88:890-894. 1998.

SINGH, R.P. \& RAJARAM, S. Resistance to Puccinia recondita f. sp. tritici in 50 Mexican bread wheat cultivars. Crop Science 31:1472-1479. 1991.

SOUSA, C.N.A. de. Survey for the presence of $\mathrm{Ne}$ genes. Annual Wheat Newsletter 42:56. 1996.

SOUSA, C.N.A. de. \& BARCELLOS, A.L. Avaliação da necrose da ponta da folha, associada ao gene $L r 34$, em cultivares de trigo. In: Anais REUNIÃO NACIONAL DE PESQUISA DE TRIGO, 18, 1999a, pp.210-213.

SOUSA, C.N.A. de. \& BARCELLOS, A.L. Avaliação da necrose híbrida em relação a linhagens de trigo desenvolvidas na Embrapa Trigo. In: Anais REUNIÃO NACIONAL DE PESQUISA DE TRIGO, 18, 1999b, pp.214-218.

THE, T.T., GUPTA, R.B., DYCK, P.L., APPELS, R., HOHMANN, U. \& McINTOSH, R.A. Caracterization of stem rust resistant derivatives of wheat cultivar Amigo. Euphytica 58:245-252. 1992.

ZOLDAN, S.M., BARCELLOS A.L. \& SOUSA, C.N.A. de. Detecção do gene $\operatorname{Lr} 13$ de resistência à ferrugem da folha em plântulas de trigo. Fitopatologia Brasileira 25:512-516. 2000. 